*УДК 336.732

Бродська I.I., к.е.н., доцент

Ткачук I.М., к.е.н., доцент

Луцький національний технічний університет

\title{
ОЦІНКА ПЛАТОСПРОМОЖНОСТІ ПОЗИЧАЛЬНИКІВ НЕБАНКІВСЬКИХ ФІНАНСОВИХ УСТАНОВ
}

У статті розглянуто наслідки достовірної оцінки платоспроможності позичальника кредитної спілки на ефективність діяльності установи у майбутньому. Досліджено та обгрунтовано найбільш прийнятні саме для кредитних спілок види забезпечень зобов'язань. Наведено показники оцінки фінансового стану позичальників. Структуровано та доповнено класифікацію документів для оцінки платоспроможності позичальників кредитних спілок. Обгрунтовано наслідки для фінансових установ у разі видачі кредиту позичальникам із низькою платоспроможністю.

Ключові слова: кредитні спілки, платоспроможність позичальників, забезпеченість кредиту, застава, поручительство.

\section{Brodska I., Tkachuk I. \\ ESTIMATION OF SOLVENCY OF BORROWERS UNBANK FINANCIAL INSTITUTIONS}

In the article importance of reliable estimation of solvency of borrower of credit union is considered on efficiency of activity of establishment. Investigational most acceptable exactly to the credit unions types of providing of obligations. The most applied providing of obligations are a guarantee and mortgage. However a mortgage is more acceptable to the credit unions of the first level of adjusting.

It is well-proven that bail is the most acceptable type of providing exactly for credit unions. Debtors bear the responsibility in obedience to the conditions of the agreement of bail. A mortgage is used by credit unions far fewer, as a notarial certification of agreement of mortgage is needed. Also an object of mortgage often is in common property of borrower and other persons, that creates additional problems at the return of credit. It is well-proven, increase of cost of credit that is provided by a mortgage. At a grant to the credit decision influence has a size of profits gets that.

Classification over of indexes of estimation of the financial state of borrowers of creditunions is brought. Indexes that characterize the real sizes of the got profits belong to the quantitative indexes. Indexes that does not depend on the concrete actions of borrower belong to the quality indexes, and already is formed as result of his past actions or events. The indexes of business reputation of borrower belong to the quality

\footnotetext{
* Бродська I.I., Ткачук I.M.
} 
indexes, marital status, and also presence of the personal and immobile chattels for a borrower, credit histories in other financial. The article classification of documents is driven for the estimation of solvency of borrowers of credit unions.

Such classification signs of documents, that is examined at a decision- making in relation to a grant to the credit to the concrete borrower, are given: docu-ments that confirm the got profits; documents that confirm profits from corporate laws; documents, that confirm the right of ownership on the personal chattels, tran-sport vehicles; documents that confirm enterprise profits.

Consequences are reasonable for financial institutions in case of delivery of credit to the borrowers with subzero solvency.

Key words: credit unions, solvency of borrowers, material credit well-being, mortgage.

\section{Бродская И.И., Ткачук И.Н. \\ ОЦЕНКА ПЛАТЕЖЕСПОСОБНОСТИ ЗАЕМЩИКОВ НЕБАНКОВСКИХ ФИНАНСОВЫХ УЧРЕЖДЕНИЙ}

В статье рассмотрены последствия достоверной оценки платежеспособности заемщика кредитного союза на эффективность деятельности учреждения в будущем. Исследовано и обоснованно наиболее приемлемые именно для кредитних союзов виды обеспечений обязательств. Приведены показателиоценки фінансового состояния заемщиков. Структурирована и дополнена классификация документов для оценки платежеспособности заемщиков кредитних союзов. Обоснованы последствия для финансовых учреждений в случае выдачи кредита заемщикам с низкой платежеспособностью.

Ключевые слова: кредитне союзы, платежеспособность заемщиков, обеспеченность кредита, залог, порука.

\section{Постановка проблеми у загальному вигляді та ії зв'язок $з$} важливими науковими та практичними завданнями. Кредитні спілки є активними учасниками фінансового ринку України з 90-х років минулого століття. Проте, щороку їх кількість зменшується, а відтак, i обсяг наданих фінансових послуг із кредитування. Це пояснюється, насамперед, негативними економічними чинниками в державі, політичною нестабільністю країни, неможливістю конкурувати із банками, оскільки останні мають значно вагоміші фінансові ресурси та надають повний спектр фінансових послуг. Окрім того, відтік працездатного населення на роботу за кордон призводить також до зменшення кількості наданих кредитів та прибутковості небанківських фінансових установ. Тому надзвичайно важливим $є$ питання достовірної оцінки плато- 
спроможності позичальників кредитних спілок, адже від вчасного повернення кредитних ресурсів залежать кінцеві результати діяльності установи, прибутковість, ліквідність, дотримання фінансових нормативів та своєчасне виконання зобов'язань кредитних спілок перед своїми членами.

Аналіз останніх досліджень, у яких започатковано вирішення проблеми. На сьогодні вітчизняні та зарубіжні науковці досліджували різноманітні питання та проблеми діяльності та розвитку кредитних спілок в Україні та світі, зокрема В. Гончаренко, А. Пантелеймоненко, Р. Максейнер, Г. Волкова, О. Калівошко, З. Криховецька, Л. Форос, М. Хуторна, Н. Савчук. Незважаючи на достатню кількість наукових публікацій у сфері функціонування кредитних спілок, питання оцінки кредитоспроможності позичальників небанківських фінансових установ потребують подальшого вивчення.

Цілі статті. Мета статті полягає в обгрунтуванні доцільності достовірної оцінки кредитоспроможності позичальників як ефективного засобу забезпечення стабільної діяльності небанківської фінансової установи в майбутньому.

Виклад основного матеріалу дослідження з повним обгрунтуванням отриманих наукових результатів. Кредитна спілка - це фінансова установа, яка функціонує з метою задоволення потреб ії членів у взаємному кредитуванні та наданні фінансових послуг за рахунок внесків іiі членів [4]. Кредитна спілка надає кредити на умовах строковості (термін дії кредитного договору), платності (розмір відсотків по кредиту) та забезпеченості (під що надається кредит). «Вибір кредитною спілкою забезпечення виконання зобов'язання за кредитом рекомендується здійснювати з урахуванням типу кредиту, кредитоспроможності позичальника, співвідношення вартості забезпечення (якщо обрана застава) до розміру кредиту, а також інші характеристики за вибором кредитної спілки» [3]. Види забезпечення виконання зобов' язання наведено на рис. 1 .

Правочин щодо забезпечення зобов'язання вчиняється в письмовій формі, якщо письмової форми не додержано, зазначений правочин $€$ нікчемним. 


\section{Порука}

\section{Застава}

\section{Гарантія}

\section{Притримання}

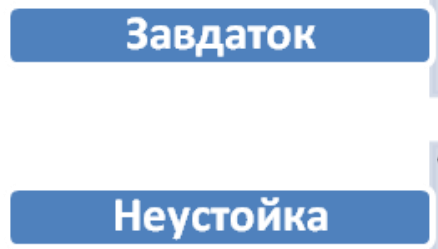

- грошова сума або рухоме майно, яке видається кредитору боржником у рахунок належних з нього задоговором платежів, на підтвердження зобов'язання і на забезпечення його виконання

- грошова сума або інше рухоме чи нерухоме майно, які передаються боржником кредитору, у разі порушення боржником зобов'язання

Рис. 1. Види забезпечення виконання зобов'язання

Варто зазначити, що при поруці боржник і поручитель несуть солідарну відповідальність перед кредитором за виконання боржником зобов'язань. На нашу думку, зазначений вид забезпечень є найбільш поширеним в діяльності саме кредитних спілок, проте має високі ризики у разі, якщо поручитель в установі є сам боржником (отримував 
кредит). При настанні несприятливих фінансових умов для поручителя, фінансова установа може мати проблеми із поверненням його кредиту, та по тому кредиту, де цей боржник є поручителем. На наше переконання, кругова порука для спілок є також неприпустимою та в майбутньому призводить до фінансових втрат.

Щодо застави, то право застави виникає з моменту нотаріального засвічення договору застави. Проте, майно, яке перебуває у спільній власності, лише за згодою всіх співвласників може передаватись в заставу. Майно, яке перебуває у спільній частковій власності, може бути самостійним предметом застави лише при умові виділення його в натуральному вимірі. Проте, на нашу думку, зазначений вид забезпечення зобов'язання $є$ поширеним для кредитних спілок першої групи регулювання (активи від 0,5 до 10 млн. грн.), оскільки нотаріальне посвідчення договорів застави значно збільшує вартість кредиту для позичальника.

Рішення щодо надання чи ненадання кредиту належить до компетенції Кредитного комітету кредитної спілки.

Кредитоспроможність позичальника є головним фактором, який впливає на рішення Кредитного комітету про надання чи ненадання кредиту, особі, яка бажає скористатись фінансовою послугою. У табл. 1 наведено показники оцінки фінансового стану позичальника згідно Методичних рекомендацій для кредитних спілок щодо проведення оцінки кредитоспроможності позичальників [3].

Таблиця 1

Показники оцінки фінансового стану позичальника [3]

\begin{tabular}{|c|c|}
\hline Кількісні показники: & Якісні показники: \\
\hline 1 & 2 \\
\hline $\begin{array}{l}\text { - чистий сукупний дохід члена } \\
\text { кредитної спілки та його сім'ї: } \\
\text { - щомісячні сукупні доходи, } \\
\text { зменшені на щомісячні сукупні } \\
\text { витрати та зобов'язання; }\end{array}$ & $\begin{array}{l}\text { - загальний матеріальний стан } \\
\text { члена кредитної спілки: } \\
\text { - наявність у власності рухомо- } \\
\text { го та нерухомого майна, крім } \\
\text { майна, переданого в заставу; }\end{array}$ \\
\hline $\begin{array}{l}\text { - накопичення у формі паїв та } \\
\text { внесків (вкладів) на депозитних } \\
\text { рахунках: } \\
\text { - } \quad \text { у кредитній спілці; } \\
\text { - } \text { на рахунках у банку; }\end{array}$ & $\begin{array}{l}\text { - } \quad \text { соціальна стабільність члена } \\
\text { кредитної спілки: } \\
\text { - наявність постійної роботи; } \\
\text { - ділова репутація; } \\
\text { - сімейний стан; }\end{array}$ \\
\hline
\end{tabular}


Продовження табл. 1

\begin{tabular}{|l|l|}
\hline \multicolumn{1}{|c|}{1} & \multicolumn{1}{|c|}{2} \\
\hline - коефіцієнти, що характеризу- & \\
ють поточну платоспроможність & \\
члена кредитної спілки і його фі- & \\
нансові можливості виконати зо- & $-\quad$ кредитна історія члена креди- \\
бов'язання за кредитом: & тної спілки: \\
- співвідношення сукупних до- & $-\quad$ інформація щодо члена кре- \\
ходів і витрат/зобов'язань члена & дитної спілки, отримана з держа- \\
кредитної спілки; & вних реєстрів та переліків, що \\
- співвідношення розміру креди- & перебувають у вільному доступі; \\
ту до вартості об'єкта кредитуван- & $\begin{array}{l}\text { рекомендації від інших членів } \\
\text { ня; }\end{array}$ \\
- співвідношення щомісячних & кредитної спілки тощо. \\
витрат члена кредитної спілки на & \\
обслуговування кредиту до обсягу & \\
його щомісячних доходів. & \\
\hline
\end{tabular}

Достовірно оцінити фінансовий стан позичальника, його платоспроможність, забезпеченість кредиту належним позичальнику майном, можна лише за умови підтверджувальних документів. Класифікацію документів, підтверджуючих платоспроможність позичальника небанківської фінансової установи наведено в табл. 2.

Таблиця 2

Класифікація документів, підтверджуючих платоспроможність позичальника кредитної спілки*

\begin{tabular}{|c|c|c|}
\hline $\begin{array}{c}\text { Класифікаційна } \\
\text { ознака документів }\end{array}$ & Види документів & Примітка \\
\hline 1 & 2 & 3 \\
\hline & & $\begin{array}{c}\text { Зазначається поса- } \\
\text { да особи та розмір } \\
\text { доходів в розрізі } \\
\text { останніх шести } \\
\text { Документи підтве- } \\
\text { рджуючі отримані }\end{array}$ \\
доходи & Довідка про доходи з місця роботи & місяців роботи. \\
& за останні шість місяців & Наявність печатки \\
& & установи та підпи- \\
& & сів посадових осіб \\
& & з місця роботи є \\
& & обов'язкова. Крім \\
\hline
\end{tabular}


"Економічні науки". - Серія "Облік і фінанси". - Випуск 16 (61). - 2019.

Продовження табл. 2

\begin{tabular}{|c|c|c|}
\hline 1 & 2 & 3 \\
\hline & & $\begin{array}{c}\text { того, ця інформа- } \\
\text { ція має бути пере- } \\
\text { вірена працівни- } \\
\text { ком Кредитного } \\
\text { комітету особисто }\end{array}$ \\
\hline & Виписка із банківського рахунка & $\begin{array}{l}\text { Завірена банківсь- } \\
\text { кою установою }\end{array}$ \\
\hline & $\begin{array}{c}\text { Документи, що підтверджують } \\
\text { отримання пенсії }\end{array}$ & $\begin{array}{l}\text { Завірені Пенсій- } \\
\text { ним фондом }\end{array}$ \\
\hline & $\begin{array}{c}\text { Документи, що підтверджують } \\
\text { отримання аліментів }\end{array}$ & $\begin{array}{c}\text { Завірені відповід- } \\
\text { ним органом соці- } \\
\text { альної політики }\end{array}$ \\
\hline & $\begin{array}{c}\text { Документи, що підтверджують } \\
\text { отримання інших платежів }\end{array}$ & $\begin{array}{c}\text { Завірені виписки } \\
\text { банківських уста- } \\
\text { нов } \\
\end{array}$ \\
\hline & $\begin{array}{c}\text { Документ, що підтверджує отри- } \\
\text { мання відсотків по банківським } \\
\text { депозитним операціям } \\
\end{array}$ & $\begin{array}{c}\text { Копія депозитного } \\
\text { договору }\end{array}$ \\
\hline & $\begin{array}{c}\text { Документ, що підтверджує отри- } \\
\text { мання процентів за внесками } \\
\text { (вкладами) членів кредитної } \\
\text { спілки } \\
\end{array}$ & $\begin{array}{c}\text { Копія депозитного } \\
\text { договору кредит- } \\
\text { ної спілки }\end{array}$ \\
\hline & $\begin{array}{c}\text { Документ, що підтверджує отри- } \\
\text { мання ренти }\end{array}$ & $\begin{array}{l}\text { Право власності на } \\
\text { об'єкт ренти, дого- } \\
\text { вір оренди }\end{array}$ \\
\hline $\begin{array}{c}\text { Документи підтве- } \\
\text { рджуючі доходи } \\
\text { отримані від кор- } \\
\text { поративних прав }\end{array}$ & $\begin{array}{c}\text { Документи, що підтверджують } \\
\text { отримання дивідендів }\end{array}$ & $\begin{array}{l}\text { Документи юри- } \\
\text { дичної особи, } \\
\text { часткою статут- } \\
\text { ного капіталу } \\
\text { якої, володіє } \\
\text { позичальник: } \\
\text { - копія установ- } \\
\text { чого договору; } \\
\text { - статут; } \\
\text { - фінансова звіт- } \\
\text { ність підприєм- } \\
\text { ства; }\end{array}$ \\
\hline
\end{tabular}


"Економічні науки". - Серія "Облік і фінанси". - Випуск 16 (61). - 2019.

Продовження табл. 2

\begin{tabular}{|c|c|c|}
\hline 1 & 2 & 3 \\
\hline & & $\begin{array}{l}\text { - податкові де- } \\
\text { кларації підп- } \\
\text { риємства. }\end{array}$ \\
\hline & $\begin{array}{c}\text { Документи, що підтверджують } \\
\text { отримання доходів від інвестицій } \\
\text { в цінні папери інших підпри- } \\
\text { ємств }\end{array}$ & $\begin{array}{c}\text { Копії цінних папе- } \\
\text { рів }\end{array}$ \\
\hline $\begin{array}{c}\text { Документи підтве- } \\
\text { рджуючі право } \\
\text { власності на неру- } \\
\text { хоме майно }\end{array}$ & $\begin{array}{c}\text { Оригінал або нотаріально посві- } \\
\text { дчена копія документу, який } \\
\text { підтверджує право власності на } \\
\text { майно, що пропонується в заста- } \\
\text { ву: } \\
\text { - договір купівлі-продажу; } \\
\text { - договір міни; } \\
\text { - договір дарування; } \\
\text { - свідоцтво про право власності } \\
\text { на нерухоме майно; } \\
\text { - свідоцтво про придбання жит- } \\
\text { лового будинку (його частини); } \\
\text { - свідоцтво про придбання іншо- } \\
\text { го нерухомого майна з прилюд- } \\
\text { них торгів; } \\
\text { - свідоцтво про право на спад- } \\
\text { щину; } \\
\text { - свідоцтво про право власності } \\
\text { у спільному майні подружжя; } \\
\text { - витяг з реєстру прав власності } \\
\text { на нерухоме майно; } \\
\text { - правовстановлюючі документи } \\
\text { на земельну ділянку, на якій } \\
\text { знаходиться предмет застави. }\end{array}$ & $\begin{array}{c}\text { Копії всіх наявних } \\
\text { документів, підт- } \\
\text { верджуючих право } \\
\text { власності на неру- } \\
\text { хоме майно пози- } \\
\text { чальника }\end{array}$ \\
\hline $\begin{array}{c}\text { Документи підтве- } \\
\text { рджуючі право } \\
\text { власності на тран- } \\
\text { спортні засоби }\end{array}$ & $\begin{array}{c}\text { Оригінал або нотаріально посві- } \\
\text { дчена копія документу, який } \\
\text { підтверджує право власності на } \\
\text { автомобіль, що пропонується в } \\
\text { заставу: } \\
\text { - договір купівлі-продажу; } \\
\text { - договір міни; } \\
\text { - договір дарування; }\end{array}$ & $\begin{array}{c}\text { Копії всіх наявних } \\
\text { документів, підт- } \\
\text { верджуючих право } \\
\text { власності на тран- } \\
\text { спортний засіб } \\
\text { позичальника }\end{array}$ \\
\hline
\end{tabular}


"Економічні науки". - Серія "Облік і фінанси" - Випуск 16 (61). - 2019.

Продовження табл. 2

\begin{tabular}{|c|c|c|}
\hline 1 & 2 & 3 \\
\hline & $\begin{array}{c}\text { - свідоцтво про реєстрацію } \\
\text { транспортного засобу; } \\
\text { - внутрішній договір } \\
\text { обов'язкового страхування } \\
\text { цивільно-правової } \\
\text { відповідальності власників на- } \\
\text { земних транспортних засобів; } \\
\text { - повне КАСКО транспортного } \\
\text { засобу. }\end{array}$ & \\
\hline $\begin{array}{c}\text { Документи, підт- } \\
\text { верджуючі доходи } \\
\text { одержані від підп- } \\
\text { риємницької дія- } \\
\text { льності }\end{array}$ & $\begin{array}{c}\text { - Свідоцтво або витяг з } \\
\text { відповідного державного } \\
\text { реєстру; } \\
\text { - Дозвільні документи на заняття } \\
\text { певними видами } \\
\text { підприємницької діяльності; } \\
\text { - Свідоцтво або витяг з } \\
\text { відповідного державного реєстру } \\
\text { про суб'єкта малого } \\
\text { підприємництва-фізичної особи } \\
\text { платника єдиного податку; } \\
\text { - Звітність за останні 6-36 } \\
\text { місяців, перевірену фіскальними } \\
\text { органами; } \\
\text { - Довідки з банку, в якому } \\
\text { обслуговується член кредитної } \\
\text { спілки, про рух коштів на його } \\
\text { рахунках за останні 6-36 місяців; } \\
\text { - Декларація про доходи } \\
\text { СПД за останні три роки }\end{array}$ & $\begin{array}{c}\text { Копії податкової } \\
\text { звітності за остан- } \\
\text { ніх три роки }\end{array}$ \\
\hline
\end{tabular}

* Структуровано та доповнено автором згідно 3 [3].

Утім, слід зазначити, що доходи отримані особою, яка бажає скористатись фінансовою послугою з отримання кредиту, мають бути регулярними. Не варто кредитній спілці враховувати разові виплати, оскільки в майбутньому періоді таких виплат може і не бути. Проте, якщо позичальником подана недостовірна, викривлена, неточна інформація щодо фінансового стану, наявності майна, інформації про непогашену 
заборгованість за кредитами в інших фінансових установах, то кредитній спілці варто утриматись від надання кредиту такому позичальнику, незважаючи на достатнє забезпечення.

Висновки. Отже, проведене дослідження надало можливість встановити, що оцінка платоспроможності позичальника та рішення кредитної спілки щодо надання чи не надання кредиту позичальнику має вирішальне значення для майбутнього функціонування кредитної спілки загалом. Адже, від цього рішення залежить: по-перше, прибутковість / збитковість фінансової установи; по- друге, наявність / відсутність витрат по нарахуванню резерву покриття втрат від неповернутих позичок; по-третє, дотримання / недотримання фінансових нормативів якості активів, коефіцієнта платоспроможності, нормативу прибутковості; по-четверте, можливості / неможливості нарахування плати (процентів) на додаткові пайові внески протягом року або за підсумками фінансового року.

1. Калівошко О.М. Оцінка діяльності кредитних спілок в Україні. Науковий вісник Ужгородського національного університету. 2019. Випуск 23. Частина 1. C. 96-103.

2. Криховецька 3.М., Форос Л.Р. Аналіз діяльності та перспективи розвитку кредитних спілок в Україні. Економіка і суспільство. 2018. №19. С. 1063-1071.

3. Про затвердження Методичних рекомендацій для кредитних спілок щодо проведення оцінки кредитоспроможності позичальників: Розпорядження Національної комісії, що здійснює державне регулювання у сфері ринків фінансових послуг від 20.11.2018 № 2006. URL:https://docs.dtkt.ua/ru/doc/v2006865-18 (дата звернення: 25.11.2019 р.).

4. Про кредитні спілки: Закон України від 20.12.2001 р. № 2908-III. Дата оновлення: 01.01.2016. URL: https://zakon.rada.gov.ua (Дата звернення: 25.11.2019 p.).

5. Савчук Н.В., Золотарьова О.В. Розвиток кредитних спілок як чинник соціальної та діяльністної мобільності в українському суспільстві. Науковий вісник Херсонського державного університету. Серія Економічні науки. 2019. Випуск 33. C. 204-208.

6. Хуторна М.Е.Розвиток системи регулювання діяльності спеціалізованих кредитних установ України як чинник підвищення їхньої фінансової стабільності. Гроші, фінанси і кредит. Науковий погляд: економіка та управління. 2019. №2 (64). C. 163-174. 